\title{
Editorial - Erosion of the Middle Class?
}

\author{
Monica BUDOWSKI ${ }^{1}$, Sebastian SCHIEF²
}

University of Fribourg

Status, development, function, and characteristics of middle positions (middle class, middle strata, middle-income group) in society are well discussed in sociology. Whether there is an erosion of these positions and what the consequences of this development for societies are is quite controversial. On the one hand, the middle positions in society are generally considered to be of major importance for the stability of a society, the economic development, and for democracy in general.(e.g., Lipset 1959). On the other hand, and much less discussed, is what happens when changes within social structure take place, especially in countries that are used to having or used to being characterized by a strong middle class. Most recent research picks up such issues of change within social structure and questions the above-mentioned characteristics and functions of the positions in the middle of society for society's stability. For example, Zick, Küpper und Berghahn (2019) state the following in their book Verlorene Mitte Feindselige Zustände (Lost Center - Hostile Conditions):

The cohesion of the middle position within society and its binding forces are constantly exposed to threats, risks and challenges. On the one hand, because it has itself become authoritarian, racist, discriminatory and exclusive, and its membership criteria are not necessarily based on democratic criteria. Moreover, membership may even rely on anti-democratic criteria, such as market laws, ethnic origin constructions or religious orientations. The greatest danger, however, is the extent to which it fundamentally loses its democratic orientation or puts it up for discussion, because it gives some members advantages, power and influence or supposedly benefits others" (Zick et al. 2019:288; own translation from German) ${ }^{3}$.

\footnotetext{
${ }^{1}$ Monica Budowski, Prof. Dr. University of Fribourg, Department of Social Policy, Social Work and Global Development: monica.budowski@unifr.ch.

${ }^{2}$ Dr. Sebastian Schief is senior lecturer in the Department of Social Policy, Social Work and Global Development: sebastian.schief@unifr.ch.

3 „Die Mitte ist ständig Gefahren, Risiken und Herausforderungen an ihren Zusammenhalt und ihre bindenden Kohäsionskräfte ausgesetzt. Einerseits, weil sie selbst autoritär, rassistisch, diskriminierend und exklusiv wird oder ihre Mitgliedschaftskriterien nach zunächst nicht unbedingt demokratischen oder sogar antidemokratischen Kriterien ausrichtet, wie etwa nach Marktgesetzen, ethnischen Volkskonstruktionen oder religiösen Orientierungen. Die grösste Gefahr ist allerdings das Ausmass, in dem sie grundsätzlich ihre demokratische Orientierung verliert oder zur Disposition stellt, weil es einigen Mitgliedern Vorteile, Macht und Einfluss verschafft oder vermeintlich anderen Nutzen hat“ (Zick et al. 2019:288).
} 
Historically, the pivotal role of the middle class is well documented. Hobsbawm (1990), for example, emphasizes that the middle class was key for the development of fascism in Italy and the Nationalsozialismus in Germany:

The soviets, even short-lived Soviet republics, were to be found not among the Czechs and Croats, but in Germany, German Austria, Hungary - and their shadow rested on Italy. Nationalism there re-emerged not as a milder substitute for social revolution, but as the mobilization of ex-officers, lower middle and middle-class civilians for counter-revolution. It emerged as the matrix of fascism (Hobsbawm 1990:130).

Hobsbawm not only emphasizes the key function of the middle class for fascism and Nationalsozialismus but also more generally for the development of nations and nationalism.

Nationalism was victorious in the formerly independent nationalities of belligerent Europe, to the extent that the movements which reflected the real concerns of the poor people of Europe, failed in 1918. When this happened, the middle and lower middle strata of the oppressed nationalities were in a position to become the ruling elites of the new independent Wilsonian petty states" (Hobsbawm 1990:130).

The analysis of size and role of the middle class in international debates on growing inequality (social polarization) points towards further social, economic, and political consequences (e.g. Piketty 2014). Looking, e.g., at the debate and growth of middle-income groups in countries of Latin America, Brooks (2015) states that traditional theoretical class models are not adequate to explain political participation, a characteristic of the middle classes considered important. Moreover, Biekart (2015) finds that the new middle classes who have been elevated out of poverty and - due to the slow-down of economic growth - the "newly disappointed" (Biekart 2015:243) middle classes, rather pursue self-caring political options. This means that their political interest lies in "maintaining a comfortable level of consumer expenditure" (Biekart 2015:243) and comes at the expense of a lesser priority for civic attitudes (social as well as environmental). The self-caring political options stand in contrast to the sharing option, where middle classes decide "for a coalition with the poor, likely leading to a more progressive agenda in which decreasing welfare levels will be combined with more social security and environmental justice" (Biekart 2015:243). Such research points towards the complexity of the role that middle classes play in society.

The special issue Erosion of the middle class? feeds into the above described debates and discusses different theoretical concepts of the middle class (middle class, middle strata, middle income groups) and its function and relevance from different thematical and regional points of view (Africa, Europe, Latin America). The contributions of the special issue debate different aspects of the middle class in Switzerland, Germany, Africa, and Latin America.

Thomas Kurer's article Routine Workers in an Increasingly Automated World of Work: Evidence from Switzerland explores the distributional consequences of technological change on mid-skilled routine workers in Switzerland in three steps: (1) The first part studies aggregate trends in the labor market and confirms the pattern of an eroding middle: the disadvantages of technological progress are concentrated on routine workers whose share in the labor force 
has strongly declined over time. (2) In order to better understand the economic conditions associated with this overall pattern, the second part draws on individual-level panel data to study actual employment transitions. The analysis shows that transitions are less frequent than the aggregate pattern might suggest: only a minority of routine workers actually switches to other jobs while the largest chunk of the decline is explained by natural transitions into retirement. (3) The last part of the paper builds on original survey data to examine routine workers' subjective assessment of their chances in a changing world of work and demonstrates a surprisingly high degree of consciousness about susceptibility to automation. To conclude, he discusses some societal implications of the hollowing of the middle.

Nicole Burzan, Silke Kohr and Miriam Schad's contribution Verunsicherung in den Mittelschichten? Konzeptionelle und methodische Erwägungen sowie empirische Befunde zu aktuellen Entwicklungen in Deutschland (Uncertainty within the Middle Strata? Conceptual and Methodological Considerations as well as Empirical Findings on Current Developments in Germany) gives an overview of the controversial debate on the increasing status-uncertainty that the (secure) German middle strata has experienced. They depart from the assumption that the controversy is not the least due to varying methodological approaches and perspectives as well as different operationalizations of a) middle social situations and b) status uncertainty in quantitative and qualitative research. Quantitative findings show that economic worries and concerns about insecurity are declining. At the same time, qualitative findings point out different dimensions of such worries: worries in different life domains, status anxiety and status insecurity. In particular, the article highlights the contribution that a combination of quantitative and qualitative methods can make quantitative methods provide an overview of the development of middle strata over time, whereas qualitative methods avail a differentiated view of specific segments of the middle strata, their particular perception of social situations, inequality-relevant orientations and agency.

Dieter Neubert's article Middle-income groups in Kenya. Conflicting Realities between upward Mobility and Uncertainty starts from the observation that for more than a decade economy and development studies' scholars have described the rise of a newly emerging middle class in the Global South including Africa. This has led to a middle class narrative with the middle class as the backbone of economic and democratic development. Especially with regards to the stability of the people's position in the middle of society, empirical social science studies challenge the middle class narrative and instead highlight the uncertainty and insecurity of these positions. Upward mobility has been accompanied by uncertainty on the one hand and instability on the other hand. Neubert terms this the vulnerability-security nexus. His contribution focuses on the options to cope with this challenge under conditions of limited provision of formal social security with a case study on Kenya. Neubert argues that it is more helpful to start from the welfare mix and the role of social networks as main elements of provision of social security than from an analysis of inequality operationalized by income. Taking into account the welfare mix and the role of social networks, the author identifies different coping strategies that conform to different sets of values and lifestyles, conceptualized as milieus and are not determined by the socio-economic status (operationalized by income and education only). 
Finally, in their contribution Die ökonomische Erforschung der lateinamerikanischen 'Mittelklassen': Ein Review aus klassentheoretischer Perspektive (The Economic Research on the Latin American Middle Classes: a Review from a Class-theoretical Perspective) Bahareh Gondani and Matthias Schulz analyze the influential economic middle class-research on Latin America. This research has gained important scientific and public attention. The authors carried out a systematic literature review. They describe and discuss the contradictory and complex results of research on Latin American middle classes in a critical manner. In a first part the numerous ways middle classes are defined and operationalized in economic research are presented and discussed. The second part traces the course of the economic debate and their conclusions. An important result is that the eighteen years of the observation period (2000-2018) can be divided roughly into two phases: in the first phase - from 2000 to 2010 -, the literature review reveals that there are a few (and single) groundbreaking essays by authors on the subject of the middle class in Latin America. These continued conducting research on the topic also in subsequent years. These publications deal with the effects of structural adjustment programs on the middle classes and aim at bringing the middle classes onto the political agenda. The middle class, considered important for democracy and economic development, came under pressure due to the structural adjustment programs and benefited too little from the reforms. The peak phase of research on the middle classes of Latin America is between 2010 to 2015. In this phase the articles focus on Latin America's economic development and their middle classes. The article concludes that from a class-theoretical perspective, the economic research on middle classes does provide valuable information on changes in income, yet as most conclusions are based on income-based definitions of class does not say much about the changes in social structure, nor about power and exploitation relationships that constitute longer-term social inequalities.

The contributions of this thematic issue link into the debate on the erosion - or in the case of the Global South, the expansion - of the middle class and present its development in different regions. The articles provide insight into different analytic and regional concepts on the middle class or middle classes, criticize the use and transposal of economic and European operationalizations or highlight the complexity of the term. We hope the contributions arouse interest and inspire for further research in the field.

\section{Bibliography}

Biekart, Kees (2015). The Choice of the New Latin American Middle Classes: Sharing or Self-Caring. European Journal of Development Research, 27(2), 238-245.

Hobsbawm, Eric (1990). Nations and Nationalism since 1780. Cambridge: Cambridge University Press.

Lipset, Seymor Martin (1959). Some Social Requisites of Democracy: Economic Development and Political Legitimacy. American Political Science Review, 53(1), 69-105.

Piketty, Thomas (2014). Capital in the Twenty-First Century (Goldhammer, Arthur, Trans.). Cambridge, MA: Harvard University Press. 
Zick, Andreas, Beate Küpper und Wilhelm Berghan (2019). Verlorene Mitte - Feindselige Zustände. Rechtsextreme Einstellungen in Deutschland 2018/2019. Bonn: Verlag J.H.W. Dietz. 